\title{
P109: Evaluation of the tolerability and acceptability of alcohol-based hand rub for hand hygiene at Fann Hospital
}

\author{
F Djiby*, Bara Ndiaye, Mery Dia
}

From 2nd International Conference on Prevention and Infection Control (ICPIC 2013)

Geneva, Switzerland. 25-28 June 2013

\section{Introduction}

The use of alcohol-based hand rubis an indirect marker of the effective implementation of hand hygiene. Caregivers are in direct contact with patients on a daily basis and use thealcohol-based hand rub during health care. Discomforts of use of this product seem to be reported by some practitioners.

\section{Objectives}

That is why we are interested in evaluating the tolerability and acceptability of the product at Fann Hospital in the exposed workers.

\section{Methods}

Among caregivers, 40 using the alcohol-based hand rubfor hand hygiene routine for at least 30 days were subjected to a questionnaire. Approximately 10 minutes were necessary to complete the questionnaire. A subjective assessment by the participant on risk factors for skin lesions, product acceptability and tolerance was thus achieved through the questionnaire.

\section{Results}

Nodermalaggressionwas reported byinterviewed caregivers.Only 5of the 40caregiversexposedreportedunpleasant odorof alcohol-based hand rub. All caregiversinterviewed reportedeasy useof the alcohol-based hand rub.

\section{Conclusion}

Alcohol-based hand rubsare acceptable andwell toleratedby practitionersduringnormal use.However, therevision of theWHOformulafor making theproductshould be

Fann Hospital, Dakar, Senegal consideredin the context ofinternational conferences toimprove the smellof the product, a factor limiting its use.

\section{Disclosure of interest}

None declared.

Published: 20 June 2013

doi:10.1186/2047-2994-2-S1-P109

Cite this article as: Djiby et al.: P109: Evaluation of the tolerability and acceptability of alcohol-based hand rub for hand hygiene at Fann Hospital. Antimicrobial Resistance and Infection Control 2013 2(Suppl 1): P109.
Submit your next manuscript to BioMed Central and take full advantage of:

- Convenient online submission

- Thorough peer review

- No space constraints or color figure charges

- Immediate publication on acceptance

- Inclusion in PubMed, CAS, Scopus and Google Scholar

- Research which is freely available for redistribution
C Biomed Central 